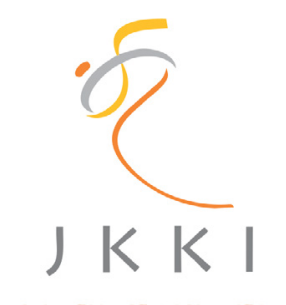

Jurnal Kedokteran dan Kesehatan Indonesia

\author{
Indonesian Journal of Medicine and Health
}

Journal homepage : https://journal.uii.ac.id/JKKI

\title{
Literature review of verbal autopsy
}

Eriliana Aryanti*1, Dhian Kartikasari², Tommy Kristanto ${ }^{2}$

${ }^{1}$ Baptis Batu Hospital, Jl. Raya Tlekung No.1, Tlekung, Kec. Junrejo, Kota Batu, Jawa Timur 65314

${ }^{2}$ Magister of Hospital Management, Faculty of Medicine, Universitas Brawijaya, Malang, Indonesia

Article Review

\begin{tabular}{l}
\hline \\
\hline ARTICLE INFO \\
\hline Keywords: \\
verbal autopsy, \\
sudden death, \\
instrument \\
\hline *Corresponding author: \\
erilianaaryanti@gmail.com \\
\hline DOI: 10.20885/JKKI.Vol11.Iss1.art12 \\
History: \\
Received: January 18, 2020 \\
Accepted: March 31, 2020 \\
Online: April 30, 2020 \\
\hline Copyright @2020 Authors. \\
This is an open access article \\
distributed under the terms \\
of the Creative Commons At- \\
tribution-NonCommercial 4.0 \\
International Licence (http:// \\
creativecommons.org/licences/ \\
by-nc/4.0/).
\end{tabular}

\section{ABSTRACT}

An sudden death is a case that occurs without prior health complaints, so that its cause cannot be identified. On a death certificate, a doctor needs to state a cause of death, so an autopsy is usually required to confirm the cause of the sudden death. Implementation of autopsies in cases of sudden deaths at the forensic medicine installation of Dr. Soetomo Hospital during 2014-2016 periods was only around 12\%. This research is a literature review. A verbal autopsy is suggested to be useful to determine a valid cause of a death; therefore, recording of deaths in the hospital will be more accurate. WHO has published various standards of verbal autopsies in 2012. Validation of the verbal autopsies by questionnaires has shown an acceptable diagnostic accuracy to identify a cause of death compared to a cause of death obtained from medical records.

Kasus kematian mendadak merupakan kasus kematian yang terjadi tanpa ada keluhan kesehatan sebelumnya sehingga tidak dapat diketahui penyebab kematian tersebut. Pada surat keterangan kematian, seorang dokter perlu memastikan sebab kematian pada kasus kematian mendadak. Sehingga diperlukan proses autopsi untuk mengkonfirmasi penyebab kematian mendadak. Pelaksanaan autopsi pada kasus kematian mendadak di Intalasi Kedokteran Forensik RSUD Dr. Soetomo pada periode 20142016 hanya sekitar 12\%. Jenis penelitian ini adalah kajian literatur. Penggunaan autopsi verbal diharapkan dapat digunakan untuk menentukan sebab kematian yang valid sehingga pencatatan kematian di rumah sakit akan semakin baik. WHO telah mempublikasikan standarstandar pelaksanaan autopsi verbal pada tahun 2012. Secara singkat, validasi kuesioner autopsi verbal telah menunjukkan akurasi diagnostik yang dapat diterima untuk menentukan penyebab kematian dibandingkan dengan penyebab kematian yang diperoleh dari catatan medis.

\section{INTRODUCTION}

A sudden death is a case that occurs without prior health complaints, so its cause cannot be identified. On a death certificate, a doctor is required to state the cause of death in a sudden death case. So an autopsy process is usually required to confirm the cause of the sudden death. Implementation of autopsies for sudden death cases in forensic medicine installation of Dr. Soetomo Hospital during 2014-2016 periods was only $12 \%$. This indicates that the implementation of forensic autopsies for cases of sudden deaths is still limited. Therefore, this becomes a challenge to improve a death registry system. One technique that is suggested to be an alternative of a forensic autopsy is verbal autopsy (AV). ${ }^{1}$

In the Joint Regulation of the Minister of Home Affairs and the Minister of Health No.15 2010 and No.162/Menkes/PB/I/2010, about 
reporting of death and causes of death, explains that a verbal autopsy is a tracing of events, conditions, symptoms, and signs of disease, that lead to a death by interviewing families or other parties who know conditions of the deceased. The verbal autopsy can be used in a communitybased mortality surveillance and research. Every death that occurs outside a health care facility must be traced to identify causes of the death.

The verbal autopsy can estimate a cause of death validly, so death recordings in health facilities can be improved. It can also be used in death surveillance and in research. This study aims to have better understanding of the verbal autopsy and its relation to legal aspects related to a health care.

\section{Death recording methods}

In the 19th century, when death-recording systems had not been implemented in a modern way in Europe, a designated officer of death surveillance would visit a home of the deceased to collect various data relating to causes of the death. Developing countries that have limited health service is still required to report the cause of death by issuing a death certificate for their citizens. In the 1950s to 1960s in Asia and Africa, systematic interviews conducted by doctors were used as alternatives to identify causes of death. A new technique, called a verbal autopsy, was used by workers of Narangwal project in India. $^{2}$

In the last two decades, there has been a growing of interest, research, and development related to all aspects of the verbal autopsy. Those includes data collection systems, contents and formats of questionnaires, targets on various age groups, processes of identifying causes of death, utilizations of a code system and tabulation of aetiologies, and validations of instruments used in the verbal autopsy. In 2007, WHO published standards of the verbal autopsy because of needs and demands related to standardization of verbal autopsies. Some of the standards for verbal autopsies include(2): a) verbal autopsy questionnaires for three age groups, such as less than 4 weeks, 4 weeks to 14 years old, and more than 15 years old; b) A certificate about the cause of death and the diagnostic code system used consistently refers to the international classification of diseases and related health problems (ICD-10); c) the last is preparing a list of causes of death for verbal autopsy according to the ICD-10.

The verbal autopsy is mainly used as a research tool in contexts of longitudinal population studies as well as intervention studies or epidemiological studies. It has become one of statistical sources to identify causes of death based on specific causes of death data at a population level, so it can be used as a basis for making policies, planning, setting priorities, and comparative studies. The verbal autopsy data can be used as a statistical source to identify causes of death used to monitor progress and evaluate success and failure. ${ }^{1}$

The verbal autopsy involves interviews with close relatives, family members, or caretakers of the deceased to collect information about signs and symptoms experienced by the deceased before death, after a culturally acceptable mourning time. This information is then analysed, either by a doctor or, more innovatively, by an automatic computer algorithm, to identify possible causes of death that can be coded according to the ICD standards. ${ }^{4} \mathrm{~A}$ home visit to conduct verbal autopsy usually is done as early as 2 weeks after the death occurs because his/her family is usually still grieving during less than 2 weeks that can make difficult to conduct interviews. ${ }^{5}$

The questionnaire of the $\mathrm{AV}$ is filled by an interviewer regarding whether the death happened at home, at the health centre, or on the way to a health facility (death on arrival/DoA). Inputting the $A V$ questionnaire, the interviewer will questioned families of the deceased about symptoms and histories of the deceased's illness during his/her life, medical histories, results of supporting examinations, and medical resumes. Results of the interview will be a basis for a doctor to input causes of death in certification form of death causes (in Indonesian called formulir keterangan penyebab kematian/FKPK). 
For deaths in a hospital, a doctor will immediately input the FKPK based on the patient's medical records. Subsequently, a descriptive analysis will be conducted by firstly coding diseases causing the death in FKPK by using the Guidelines of Disease Encoding Book ICD-10 (Volume 1,2,3). Mortality data collected by puskesmas (public health service) staff will be coded by a code clerk of the health department, while mortality data from a hospital will be coded by a hospital medical record officer. Then the data will be sent to National Institute of Health Research and Development, Indonesian Ministry of Health. After a process of editing, entering and cleaning, the data were analysed by grouping basic causes of death based on tabulation 1 or classification of diseases on ICD-10. ${ }^{6}$

Globally, there are only one third of reliable causes of death registered. Lack of vital registration to provide representative data is mostly found in developing countries. Output of this $\mathrm{AV}$ questionnaire is a disease causing death classified according to the ICD-10. A main purpose of verbal autopsy is to identify levels and causes of death in a community. In conclusion, It can function as an alternative solution to improve a quality of death registration system in developing countries, especially Indonesia. ${ }^{7}$ In a population level, this information is very valuable to help directing priorities, health policies and services. ${ }^{8}$

Some studies state that incomplete input of symptom items accompanying death is influenced by lack of carefulness of some nurses in completing each question in the verbal autopsy questionnaire. Incomplete information also can cause incompleteness of the verbal autopsy questionnaire data. For example, a deceased whose cause of death was stroke showed no symptoms of paralysis in his/her limbs. However, in a summary of disease history, a nurse wrote that the deceased was unable to move before his death. This shows inconsistency when inputting the verbal autopsy questionnaire. In the verbal autopsy questionnaire, there is a group of questions specifically intended for deceased women aged 10-54 years old, but some nurses are reluctant to complete the questionnaire because there are too many questions in the questionnaire. Some nurses are also reluctant to check the completeness of every question in the questionnaire. ${ }^{9}$

Some studies also state that nurses are less consistent to explore information about what health cares are received by the deceased. For example, in the questionnaire that the nurse tells the history of the deceased's illness, the nurse states that the deceased previously went to a private doctor's practice before death. ${ }^{9}$ However, in some cases, questions about previous health cares were empty. All Puskesmas that conducted verbal autopsies after reporting death in less than 24 hours was only 3 of Puskemas wrote in the form. ${ }^{10}$

Information of death events was obtained from population administrators and staffs. Furthermore, this information was traced by health workers to determine the deceased cause of death by using the AV questionnaire and inputting the FKPK. Developing this system can produce information about mortality rates and patterns of causes of death. ${ }^{11}$

Based on this literature study, it can be seen that only $52 \%$ of symptom checklists of causes of death were completely inputted by some nurses. The highest complete records were found in the death information filled by some doctors, who later will determine the cause of death. The summary of disease history was found complete in $54 \%$, while the health service received was found complete in $66 \%$. Then there is a significant relationship between the completeness of the verbal autopsy questionnaire with the accuracy of identifying the cause of death. ${ }^{9}$

Some implementations the verbal autopsy were in accordance with the guidelines although some are not. The implementation is in accordance to the guidelines when who input the $\mathrm{AV}$ have received training, when the identification of death cause is in accordance with the Indonesian Ministry of Health, and when the AV is in accordance to the City Health Department requirements. Meanwhile, the AV implementation is not in accordance because 
there is no work and procedure instruction (instruksi kerja dan prosedur kerja or IK/PK) about the AV implementation, no inputting of FKPK and death certificate service, no ratified death certificate service, and no clear standards. In addition, there are different opinions regarding acceptable mourning time for the deceased's family; respondents interviewed are not always the deceased's family understanding the deceased's health history; percentage of coding of causes of death is $37.21 \%$; and there are different understanding between the health department and Puskesmas regarding the date of sending the report to the health office. ${ }^{12}$

AV sensitivity is at least $75 \%$ in identifying several major causes of death such as strokes, road traffic accidents, and some site-specific cancers. However, its sensitivity is less than $50 \%$ for other important causes including ischemic heart diseases, chronic obstructive pulmonary diseases, and diabetes. Overall, there was 57\% accordance between underlying causes of death from the $\mathrm{AV}$ and medical records that increased to $76 \%$ when several causes of $\mathrm{AV}$ were compared to underlying causes of death from medical records. ${ }^{13}$ Validation of the verbal autopsy questionnaire had shown acceptable diagnostic accuracy to identify the cause of death compared to the cause of death obtained from medical records. This can function as an acceptable substitute for certifying the cause of death when the latter cannot be obtained. ${ }^{14}$ The questions that mostly contribute to COD predictions are also the most reliable and consistent questions in all of these repeated interviews that have been included in the short form of AV questionnaire. The accuracy and reliability of the diagnosis for individual deaths depend on the quality of the interview. This has considerable implications for the progressive launch of $A V$ into the civil registration and vital statistics (CRVS) system. ${ }^{15}$

\section{CONCLUSION}

One of ways to improve the death registration system, which can be considered representative currently, is the verbal autopsy. It is a tracing process of events that lead to a death, by interviewing families or other parties who understand conditions of the deceased. It is suggested to be an alternative solution in improving a quality of a death registration system. A good record of mortality can help identifying health problems, priorities and interventions in the field of public health. In addition, it can produce information about mortality rates and patterns of causes of death that occur in the community.

\section{CONFLICT OF INTEREST}

There is no conflict of interest.

\section{ACKNOWLEDGEMENT}

None declare

\section{REFERENCES}

1. Pratiwi AI. Autopsi verbal pada kasus kematian mendadak di instalasi kedokteran forensik RSUD Dr. Soetomo pada 1 November 2017 - 30 November 2017. Qanun Medika. 2018;2(2).

2. WHO. Verbal autopsy standards: The 2012 WHO verbal autopsy instrument. Geneva: WHO Press; 2012.

3. Rumanga W, Rombot D, Palandeng HMF. Gambaran autopsi verbal pasien yang meninggal karena tuberkulosis di kota Manado. Jurnal kedokteran komunitas dan tropik. 2015;3(1).

4. Savigny D de, Riley I, Chandramohan D, Odhiambo F, Nichols E, Notzon S, et al. Integrating community-based verbal autopsy into civil registration and vital statistics (CRVS): system-level considerations. Glob Health Action. 2017;10(1):1272882.

5. Konadi L, Bisara D, Ghani L, Pangaribuan L, Teja T, Irianto J, et al. Angka kematian dan faktor risiko stroke sebagai penyebab dasar kematian di kabupaten Padang Pariaman provinsi Sumatera Barat. Buletin Penelitian Kesehatan. 2016;44(4):227-36.

6. Simarmata OS, Lolong DB, Pangaribuan L, Sulistiyowati N, Sulistiowati E. Penyebab kematian di kabupaten Gianyar tahun 2010-2012. Buletin Penelitian Kesehatan. 
2018;46(2):77-86.

7. Karina S, Yunus A, Meilani C, Khasanah U, Ismiyati GN. Otopsi verbal sebagai alternatif otopsi konvensional. Jurnal Pro Justisia. 2010;12(4).

8. Gouda HN, Flaxman AD, Brolan CE, Joshi R, Riley ID, AbouZahr C, et al. New challenges for verbal autopsy: Considering the ethical and social implications of verbal autopsy methods in routine health information systems. Social Science \& Medicine. 2017;184:65-74.

9. Ninawati N, Sugiarsi S. Hubungan antara kelengkapan pengisian kuesioner auto psi verbal dengan keakuratan penentuan sebab dasar kematian di puskesmas wilayah Surakarta. Jurnal Manajemen Informasi Kesehatan Indonesia. 2015;3(1):38-42.

10. Fahmi MA. Evaluasi program audit maternal perinatal (AMP) di kabupaten Temanggung Jawa Tengah. Jurnal Penelitian Kesehatan SUARA FORIKES. 2017 Apr 24;8(3):109-15.

11. Sulistiyowati N, Senewe FP. Penerapan model pengembangan sistem registrasi kematian dan penyebab kematian di kabupaten/kota daerah pengembangan. Jurnal Ekologi Kesehatan. 2014;13(1):23-32.

12. Novitasari E, Istiono W. Evaluasi pelaksanaan autopsi verbal di puskesmas Jetis kota Yogyakarta. Universitas Gadjah Mada; 2014

13. Tran HT, Nguyen HP, Walker SM, Hill PS, Rao C. Validation of verbal autopsy methods using hospital medical records: a case study in Vietnam. BMC Medical Research Methodology. 2018;18(1):43.

14. Mondal R. Validity of verbal autopsy for assessment of causes of death in Bangladesh. European Academic Research. 2015; 3(8): 8725-40.

15. Serina P, Riley I, Hernandez B, Flaxman AD, Praveen $D$, Tallo $\mathrm{V}$, et al. The paradox of verbal autopsy in cause of death assignment: symptom question unreliability but predictive accuracy. Population Health Metrics. 2016;14(1):41. 